\title{
PENGARUH KOMUNIKASI SOSIAL MEDIA TERHADAP PERSEPSI KONSUMEN PADA PRODUK KOSMETIK HALAL
}

\author{
Oleh: \\ Yulfan A. Nurohman \\ Dosen IAIN Surakarta \\ Rina Sari Qurniawati \\ Dosen Tetap STIE AMA Salatiga
}

\begin{abstract}
Abstrak
Akhir-akhir dengan meningkatnya teknologi informasi khususnya internet, ini teknik pemasaran melalui sosial media semakin berkembang. Peneliti dan manajer pemasaran sebuah perusahaan memiliki pemahaman yang terbatas tentang peran dari komunikasi sosial media pada ekuitas merek, sikap pada merek, dan minat pembelian. Kemampuan platform media sosial untuk menanamkan diri pada gaya hidup banyak pengguna mereka seharusnya dirasakan sebagian besar sebagai peluang oleh perusahaan yang ingin menggunakan platform semacam itu untuk menghasilkan dan meningkatkan hubungan dengan pelanggan.

Penelitian ini menggunakan 99 responden muslim yang ada di Surakarta mengunakan metode survei. Untuk menguji model, peneliti meneliti konsumen produk kosmetik berlabel halal. Pengujian pada penelitian ini menggunakan regresi sederhana. Program statistik SPSS digunakan untuk menguji validitas dan reliabilitas instrument dan hipotesis penelitian.

Hasil dari penelitian ini adalah terdapat hubungan antara komunikasi media sosial baik pada ekutitas merek dan sikap pada merek. Variabel ekuitas pada merek dan sikap pada merek juga terbukti berpengaruh terhadap minat pembelian kosmetik halal. Dengan demikian, pengujian dari semua hipotesis yang ada didukung.
\end{abstract}

Kata kunci: komunikasi media sosial, ekuitas merek, sikap merek, minat pembelian, kosmetik halal

\section{PENDAHULUAN}

Sekarang ini cara dan strategi pemasar dalam berkomunikasi dengan konsumen secara signifikan telah berubah sejak munculnya internet, khususnya sosial media. Sosial media mencakup diantaranya, forum online, blog, forum diskusi yang disponsori oleh perusahaan, situs dan forum layanan konsumen, dan situs jejaring sosial (Mongold dan Faulds, 2009). Situs sosial media menarik jutaan pengguna yang kebanyakan dari mereka 
mengintegrasikan hal tersebut kedalam kehidupan sehari-hari dan praktek bisnis. Perubahaan lain yang muncul akibat dari adanya sosial media adalah perubahan pengambilan keputusan oleh konsumen. Misalnya, situs sosial media menyediakan forum publik yang memberikan ruang bagi konsumen untuk menyuarakan pengalaman mereka dalam pembelian sebuah produk (Kozinets et.al, 2010).

Dalam beberapa tahun terakhir, manajemen merek menghadapi dua kecenderungan yang berlawanan, yaitu hilangnya keaslian merek dan meningkatnya pengaruh konsumen pada komunikasi sebuah merek. Sosial media telah merubah tatanan komunikasi pemasaran tradisional. Pada jaman dulu, komunikasi sebuah merek dilakukan dan dikontrol oleh merek itu sendiri dan manajer pemasaran tetapi saat ini komunikasi itu dibentuk oleh konsumen (Schivinski dan Dabrowski, 2013).

Pesatnya pertumbuhan popularitas sosial media dalam beberapa tahun terakhir telah menimbulkan pertanyaan apakah fenomena ini akan mengurangi control pemasar terhadap manajemen merek (Berthon et al., 2007). Sosial media menawarkan kesempatan bagi pelanggan untuk berinteraksi dengan konsumen yang lain di seluruh dunia, dengan demikian perusahaan bukan lagi menjadi satu-satunya sumber informasi sebuah merek (Li dan Bernoff, 2011). Apalagi saat ini semakin banyak konsumen yang mencari informasi tentang sebuah produk mengunakan sosial media sehingga akan lebih meyakinkan mereka akan pemilihan sebuah merek dari produk yang akan mereka beli. Selain itu, konsumen kini beralih dari media tradisional seperti TV, radio dan majalah ke sosial media untuk mencari informasi (Mangold dan Faulds, 2009).

Menurut sebuah studi yang dilakukan oleh Nielsen (2009), $70 \%$ pengguna internet mempercayai ulasan atau review dari konsumen di sosial media tentang suatu produk. Akibatnya, pemasar bisa menduga bahwa komunikasi merek tidak hanya bisa dilakukan oleh perusahaan akan tetapi juga dapat dilakukan oleh konsumen melalui sosial media. Oleh karena itu sangat penting untuk membedakan antara komunikasi sosial media yang dilakukan oleh perusahaan dan yang dilakukan oleh konsumen. Hal ini penting 
karena sosial media yang dibuat oleh perusahaan akan di bawah kendali perusahaan, sedangkan komunikasi sosial media oleh konsumen tidak terikat oleh perusahaan.

Dalam pemasaran, saat ini ada minat yang meningkat pada interaktivitas digital, terutama dalam aktivitas konsumen di sosial media. Teknologi informasi memberdayakan konsumen, dan peran mereka beralih dari penyampaian informasi pasif menjadi generator informasi aktif (Stewart dan Pavlou, 2002). Seiring dengan meningkatnya aktivitas konsumen yang sebelumnya dikendalikan oleh perusahaan, keseluruhan lanskap pemasaran berubah. Oleh karena itu, perusahaan perlu lebih memahami perubahan perilaku konsumen, agar tercipta saling menguntungkan dari penggunaan sosial media. Perilaku online konsumen berkembang dengan cepat. Konsumen mengambil bagian dalam berbagai kegiatan mulai dari mengkonsumsi konten, berpartisipasi dalam diskusi, dan berbagi pengetahuan dengan konsumen lain untuk berkontribusi pada aktivitas konsumen lainnya.

Selama 10 tahun terakhir, agama semakin penting, sejajar dengan faktor sosial ekonomi dan politik, dalam mempengaruhi perilaku konsumen di pasar negara berkembang. Pemasar jadi lebih tertarik untuk mengembangkan strategi branding yang spesifik (yaitu berdasarkan iman) yang secara tepat menargetkan kelompok etnis tertentu. Munculnya konsumen Muslim sebagai segmen pasar yang menjanjikan - yang memiliki daya beli yang meningkat, yang anggotanya tertarik pada konsumsi modern namun tetap peka terhadap Nilai iman mereka (Nasr, 2009).

Kosmetik saat ini dapat diklasifikasikan sebagai suatu barang yang harus dimiliki, tidak hanya untuk wanita tapi juga untuk minoritas pria dengan kepribadian metroseksual. Meningkatnya jumlah umat Islam di seluruh dunia dan peningkatan kesadaran di antara mereka adalah dua alasan penting dibalik munculnya perubahan perilaku di kalangan konsumen Muslim. Umat Islam sadar yang akan larangan penggunaan Alkohol, daging babi dan barang-barang terkait lainnya, menyebabkan adanya peningkatan permintaan untuk kosmetik dan perawatan pribadi yang halal. Patton (2009) menyatakan bahwa permintaan kosmetik Halal di seluruh dunia terus meningkat, tidak hanya didorong oleh 
konsumen Muslim yang lebih kaya namun juga semakin tertarik dengan produk berkualitas tinggi dan aman.

Fadahunsi dan Kargwell (2015) menyatakan bahwa banyak dari perusahaan yang memproduksi produk halal atau dengan cara lain terlibat dengan pasar Muslim telah memperkenalkan produk mereka secara online melalui situs web mereka. Akan tetapi setelah diamati, menunjukkan bahwa relatif sedikit yang secara aktif memanfaatkan interaktivitas online yang difasilitasi oleh media sosial, dan Potensi yang dimiliki untuk peningkatan hubungan yang mereka miliki dengan pelanggan mereka. Berdasarkan uraian di atas, penulis tertarik untuk melakukan penelitian yang bertujuan untuk menguji pengaruh komunikasi sosial media pada niat membeli produk halal pada konsumen di Surakarta, Jawa Tengah.

\section{Rumusan Masalah}

Berdasarkan latar belakang di atas, maka rumusan masalah pada penelitian ini adalah

1. Apakah komunikasi sosial media berpengaruh positif terhadap ekuitas merek kosmetik halal?

2. Apakah komunikasi sosial media berpengaruh positif terhadap sikap pada merek kosmetik halal?

3. Apakah ekuitas merek berpengaruh positif terhadap minat pembelian kosmetik halal?

4. Apakah sikap pada merek berpengaruh positif terhadap minat pembelian kosmetik halal?

\section{Tujuan Penelitian}

Sesuai dengan permasalahan penelitian, maka tujuan penelitian ini adalah:

1. Menemukan bukti empiris adanya pengaruh komunikasi sosial media terhadap ekuitas merek dan sikap pada merek kosmetik halal

2. Menemukan bukti empiris adanya pengaruh ekuitas merek dan sikap pada merek terhadap minat pembelian kosmetik halal 


\section{Manfaat Penelitian}

Penelitian diharapkan akan memberi manfaat baik peneliti, praktisi, maupun akademisi. Adapun manfaat penelitian ini adalah:

\section{Bagi Peneliti}

Penelitian ini bermanfaat untuk dapat lebih memperdalam ilmu pemasaran dan perilaku konsumen, khususnya pemasaran melalui sosial media

\section{Bagi Praktisi}

Penelitian ini diharapkan dapat memberikan sumbangan informasi dan pemikiran bagi praktisi (pemasar) untuk menjadi bahan pertimbangan bagaimana seharusnya mempelajari perilaku pembelian yang dilakukan dengan menggunakan media internet (online) khususnya melalui sosial media. Dengan demikian pemasar dapat menerapkan startegi-strategi khusus yang dapat meningkatkan penjualan mereka.

\section{Bagi Akademisi}

Hasil penelitian yang didapatkan nanti diharapkan dapat berguna sebagai bahan pertimbangan bagi penelitian selanjutnya, terutama untuk penelitian yang berkaitan dengan faktor-faktor yang menjadikan sosial media sebagai alat bantu pembuat keputusan bagi konsumen dalam melalukan pembelian.

\section{LANDASAN TEORI}

\section{Komunikasi Sosial Media}

Dominasi teknologi Web 2.0 dan sosial media telah menyebabkan pengguna internet di seluruh dunia bisa bertemu, salah satunya adalah dengan menggunakan jejaring sosial. Jaringan melalui media online dapat diartikan sebagai sumber informasi digital yang diinisiasi, diedarkan dan dikonsumsi oleh penggunak internet, sebagai salah satu cara untuk mendidik satu sama lain tentang produk, merek, layanan, kepribadian, dan isu (Chauhan dan Pillai, 2013). Perusahaan sekarang sadar akan pentingnya fokus pada pengembangan hubungan dua arah dengan pelanggan untuk mendorong interaksi yang lebih baik (Li dan Bernoff, 2011). Lebih lanjut, sosial media menawarkan baik 
kepada perusahaan maupun konsumen jalan baru untuk saling mengikat. Manajer pemasaran mengharapkan komunikasi melalui sosial media akan membuat konsumen lebih setia dan mempengaruhi persepsi konsumen akan sebuah produk lalu menyebarkannya kepada calon konsumen baru (Brodie et al, 2013).

Aktivitas konsumen di sosial media adalah berdasarkan seberapa aktif atau pasif konsumen berperilaku online. De Valck et al. (2006) mengidentifikasi enam perbedaan tipe anggota komunitas virtual berdasakan partisipasi/komunikasi anggota, (1) Anggota inti adalah mereka yang berkontribusi paling banyak di masyarakat dengan mengambil informasi, memasok informasi dan berdiskusi, (2) Pembicara, berfokus pada mendiskusikan informasi, (3) Informan terutama mengambil dan memasok informasi, (4) Penggemar fokus pada pemeliharaan dan memperbarui informasi pribadi mereka di situs web, (5) Fungsionalis tertarik untuk mengambil informasi, (6) Oportunis hanya menerima konten marjinal dari situs web. Katagorisasi ini didasarkan pada aktvitas informasi dan tidak termasuk jenis kegiatan lainnya.

Di era informasi ini, konsumen menggunakan sosial media untuk mengakses produk yang diinginkan dan informasi akan suatu merek (Li dan Bernoff, 2011). Era sosial media ini juga berakibat pada berubahnya proses pengambilan keputusan konsumen dan komunikasi pemasaran oleh suatu perusahaan. Ketika perusahaan mulai menyadari nilai internet sebagai komponen utama dari platform komunikasi mereka, perusahaan mulai memanfaatkan praktek pemasaran alternatif yang lebih hemat biaya dan lebih efisien untuk terlibat secara aktif dengan konsumen daripada melalui saluran iklan tradisional.

Situs jejaring sosial memungkinkan pemasaran viral dan promosi dari mulut ke mulut yang sama efektifnya /lebih efektif daripada media tradisional karena tingginya tingkat keterlibatan konsumen yang terkait dengan bentuk alternatif media berbasis web ini (Castronovo dan Huang, 2012). Kemampuan platform media sosial untuk menanamkan diri pada gaya hidup banyak pengguna mereka seharusnya dirasakan sebagian besar sebagai peluang oleh perusahaan yang ingin menggunakan platform semacam itu untuk menghasilkan dan meningkatkan hubungan dengan pelanggan. Pada saat ini, belum banyak perusahaan yang menggunakan platform media sosial untuk 
berhubungan dengan pelanggan yang menjelaskan pada nilai dan ajaran Islam dalam produk yang dibuatnya sehingga peluang awala bagi perusahaan yang akan melakukannya. Hal ini untuk memposisikan merek mereka secara berbeda dari yang dimiliki pemasar sekuler dan lainnya.

\section{Ekuitas Merek}

Konsep ekuitas merek adalah aset pemasaran utama (Styles dan Ambler, 1995) yang dapat menghasilkan hubungan yang membedakan ikatan antara perusahaan dan konsumen serta memelihara hubungan jangka panjang (Keller, 2013). Pengukuran ekuitas merek dalam literatur dapat dilihat dari dua perspektif yaitu perspektif keuangan dan perspektif berbasis pelanggan. Menurut Aaker (1991; 15), ekutitas merek dapat didefinisikan sebagai seperangkat aset dan kewajiban merek yang terkait dengan merek, nama, dan simbol yang menambah atau mengurangi nilai yang diberikan oleh produk atau layanan kepada perusahaan atau pelanggan perusahaan tersebut.

Proses perolehan informasi konsumen tergantung pada sumber informasi (eksternal dan ekternal) yang secara bersama-sama akan mempengaruhi penilaian ekuitas merek dan pilihan merek secara keseluruhan (Beales et al., 1981). Komunikasi merek secara positif mempengaruhi ekuitas merek selama pesan tersebut menciptakan reaksi yang konsumen yang memuaskan terhadap produk yang bersangkutan dibandingkan dengan produk non-merek yang serupa (Yoo, Donthu dan Lee, 2000). Selain itu rangsangan komunikasi akan mengakibatkan efek positif pada konsumen sebagai penerimanya; oleh karena itu persepsi komunikasi secara positif mempengaruhi kesadaran seseorang terhadap merek (Bruhn, Schoenmueller, dan Schafer, 2012).

Penelitian sebelumya juga menunjukkan bahwa komunitas merek dapat meningkatkan ekuitas merek dengan memanfaatkan ekuitas merek. Caranya adalah dengan meningkatkan probabilitas bahwa sebuah merek akan dipertimbangkan ketika seorang pelanggan akan membeli suatu produk, sehingga membantu dalam proses pengambilan keputusan merek (Yoo, Donthu,dan Lee, 2000). Berdasarkan teori skema Eysenck (1984), landasan teoritis tradisional tentang hubungan antara komunikasi dan ekuitas merek, kami menduga bahwa komunikasi sosial media berpengaruh secara langsung terhadap ekuitas merek dan sikap terhadap merek. Kerangka kerja tersebut 
menggambarkan bahwa konsumen membandingkan rangsangan komunikasi dengan pengetahuan tersimpan mereka tentang aktivitas komunikasi yang sebanding.

H1: Komunikasi sosial media akan berpengaruh positif terhadap ekuitas merek kosmetik halal

\section{Sikap pada Merek}

Menurut Mitchell dan Olson (1981), sikap merek didefinisikan sebagai " keseluruhan evaluasi konsumen terhadap merek". Sikap merek sering dikonseptualisasikan sebagai evaluasi global yang didasarkan pada reaksi yang menguntungkan atau tidak menguntungkan terhadap rangsangan atau kepercayaan terkait merek (Murphy dan Zajonc 1993) dan dikutip sebagai komponen utama sebagai hal yang dipertimbangkan dalam ekuitas merek berbasis konsumen dan pertukaran relasional ( Lane dan Jacobson 1995; Morgan dan Hunt 1994). Model sikap multiattribute (I. Ajzen dan Fishbein 1980) mendalilkan bahwa secara keseluruhan evaluasi sebuah merek adalah fungsi dari keyakinan tentang atribut spesifik dari merek / produk.

Terdapat konsensus yang diakui bahwa komunikasi antara konsumen merupakan sumber transmisi informasi yang berpengaruh (Dellarocas, Zhang, dan Awad, 2007). Karena perkembangan dan perluasan sosial media, komunikasi antar individu yang tidak saling kenal dapat dipercepat (Duan, Gu, dan Whinston, 2008). Dalam konteks ini, Li dan Bernoff (2011) menunjukkan bahwa saluran sosial media merupakan alternatif biaya yang efektif untuk mendorong komunikasi peer-to-peer. Percakapan dari konsumen ke konsumen juga ditemukan sebagai pendorong penting hasil bagi perusahaan (Burmann dan Arnhold 2008).

H2: Komunikasi sosial media akan berpengaruh positif terhadap sikap pada merek kosmetik halal

\section{Minat Pembelian Produk Kosmetik Halal}

Minat beli konsumen menurut Kotler (2003:205) adalah sesuatu yang timbul setelah menerima ransangan dari produk yang dilihatnya, dari sana timbul ketertarikan untuk mencoba produk tersebut sampai pada akhirnya membeli agar dapat memilikinya. Minat beli merupakan sesuatu yang berhubungan dengan rencana konsumen untuk membeli produk tertentu serta berapa banyak unit produk yang dibutuhkan pada periode 
tertentu,dapat dikatakan bahwa minat beli merupakan pernyataan mental dari diri konsumen yang merefleksikan rencana pembelian sejumlah produk dengan merek tertentu.

Penelitian sebelumnya telah menyarankan bahwa tingkat tinggi pembelian ekuitas merek mendorong pembelian merek yang sama (Yoo dan Donthu 2001). Kosumen setia cenderung membeli lebih dari konsumen biasa atau baru (Yoo, Donthu, dan Lee 2000). Sikap positif terhadap merek mempengaruhi niat pembelian pelanggan (Keller dan Lehmann 2003). Selain itu, persepsi konsumen yang lebih positif tentang keunggulan merek dikaitkan dengan niat pembelian yang lebih kuat (Aaker 1991).

Dalam bahasa Arab, Halal berarti "diperbolehkan" atau "sah", sedangkan yang berlawanan, Haram, berarti dilarang atau melanggar hukum (Alam dan Sayuti, 2011; Wilson dan Liu, 2010). Pemahaman umum adalah bahwa produk halal tidak boleh terkontaminasi dengan daging babi atau alkohol dan bahwa ternak harus disembelih sesuai dengan hukum Syariah Islam. Popularitas Halal yang berkembang dapat dikaitkan dengan semangat religius serta kepercayaan bahwa itu lebih bersih, lebih sehat dan lebih lezat (Al-Harran dan Low, 2008). Dalam sebuah laporan tentang produk perawatan pribadi dan kosmetik halal, Hunter (2012) menyatakan bahwa karena peningkatan internalisasi pasar, lebih banyak pilihan produk pasar yang terdiri dari formulasi bahan baru telah tersedia bagi konsumen. Beberapa bahan ini dianggap tidak sesuai untuk konsumen Muslim berdasarkan Hukum Islam karena sumber dan metode pengolahannya

H3: Ekuitas merek akan berpengaruh terhadap minat pembelian kosmetik halal H4: Sikap pada merek akan berpengaruh terhadap minat pembelian kosmetik halal 


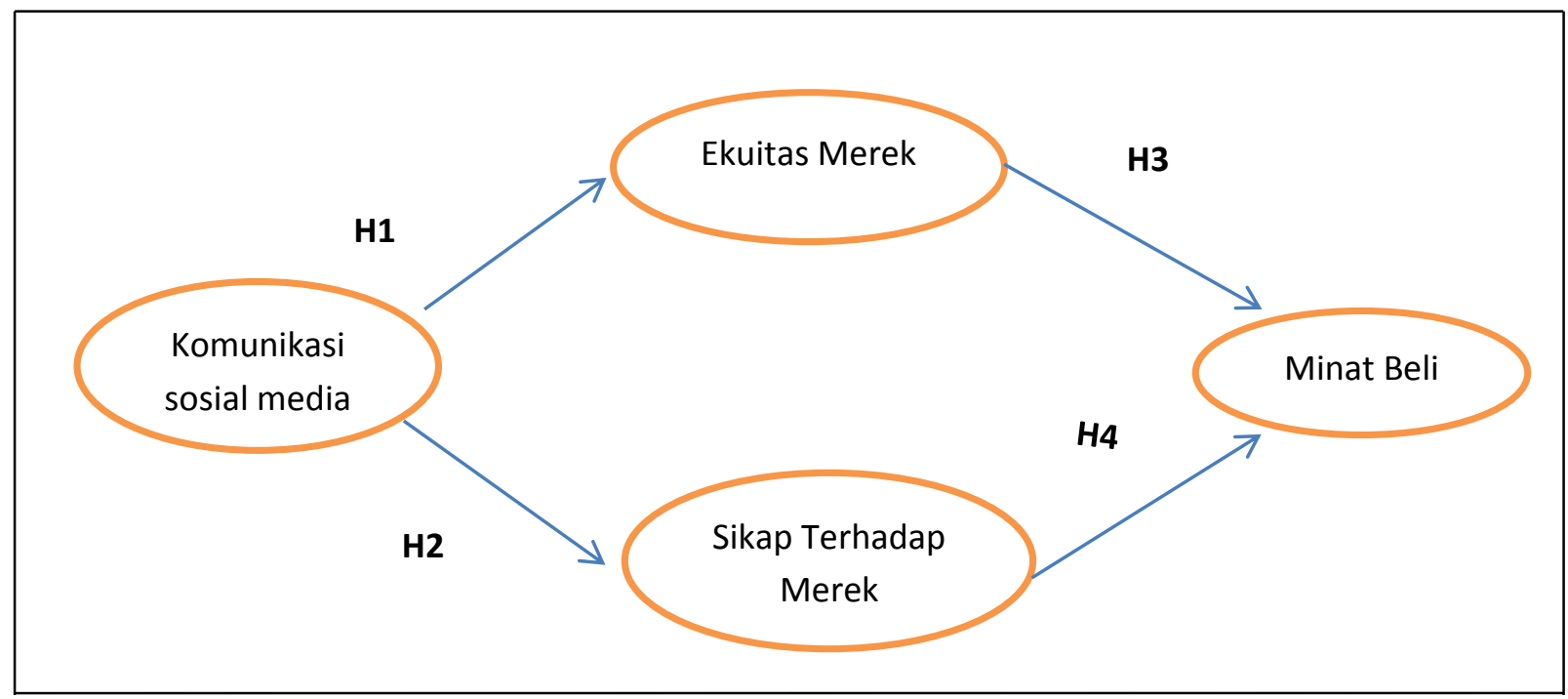

Gambar 1

Skema Rancangan Penelitian

\section{METODE PENELITIAN}

1. Sampel dan data

Indonesia sebagai salah satu negara dengan penganut muslim terbesar di dunia menjadi pangsa pasar yang besar bagi produk halal. Selain itu, di Indonesia sendiri sudah ada lembaga yang mengelurarkan sertifikasi halal yang dikeluarkan oleh LP POM MUI (Lembaga Pengkajian Pangan, Obat, dan Kosmetik Majelis Ulama Indonesia). Oleh karena itu, Indonesia khususnya kota Surakarta terpilih sebagai negara tempat studi ini dilakukan. Penelitian ini menggunakan kuesioner self-administrated dengan pertanyaan tertutup. Kuesioner tersebut didistribusikan dengan menggunakan teknil convenience sampling non-probabilitas. Metode ini merupakan alternatif karena keterbatasan waktu, kecepatan, biaya dan kenyamanan untuk mendapatkan jumlah responden yang cukup. Convenience sampling telah banyak digunakan sebagai teknik pengambilan sampel, terutama di bidang penelitian pemasaran dan perilaku konsumen (lihat Alam dan Sayuti, 2011b; Aertsens dkk., 2011). Pada akhir periode pengumpulan data, total 99 kuesioner yang dapat digunakan dari responden wanita Muslim berusia di atas 18 tahun digunakan untuk analisis lebih lanjut. Tabel 1 memperlihatkan karakteristik responden dalam penelitian ini. 


\section{Tabel 1}

\section{Karakteristik Responden}

\begin{tabular}{|l|c|}
\hline \multicolumn{1}{|c|}{ Karakteristik } & Presentase (\%) \\
\hline \multicolumn{1}{|c|}{ Usia } & $52.5 \%$ \\
17-20 & $47.5 \%$ \\
21-22 & \\
Pendidikan & $2 \%$ \\
SMA & $98 \%$ \\
S1 & \\
Pengeluaran dalam 1 bulan & $1 \%$ \\
>Rp. 100.000 & $17.2 \%$ \\
Rp. 100.000 - Rp. 250.000 & $23.2 \%$ \\
Rp. 250.000-Rp. 500.000 & $34.5 \%$ \\
Rp. 500.000 - Rp. 1.000.000 & $23.2 \%$ \\
< Rp. 1.000.000 & \\
\hline
\end{tabular}

\section{Pengukuran}

Pengukuran komunikasi sosial media menggunakan item pertanyaan yang diadaptasi dari Schivinski dan Dabrowski (2013), terdiri dari 5 pertanyaan dengan 5 skala likert untuk menunjukkan peran sosial media dalam berkomunikasi tentang suatu merek (Cronbach alpha 0,83). Pengukuran pada ekuitas merek secara keseluruhan didsptasi dari Yoo dan Donthu (2001), juga terdiri dari lima skala Likert 5 poin mulai dari 1 (sangat tidak setuju) sampai 5 (sangat setuju ), Menanyakan responden tentang preferensi konsumen dalam memilih produk kosmetik halal (Cronbach's alpha 0,79). Ukuran pada sikap pada produk kosmetik Halal diadaptasi dari dua studi (Low dan Jr., 2000; Vilarejo-Ramos dan SanchezFranco., 2005). Konstruksi ini juga diukur pada lima skala Likert 5 poin dengan skor Cronbach's alpha sebesar 0,78. Akhirnya, lima skala Likert 5 poin juga digunakan untuk mengukur minat konsumen dengan Cronbach's alpha sebesar 0,8. Semua ukurannya dapat diandalkan, karena alfa Cronbach melebihi 0,70 (Nunnally, 1978). 


\section{ANALISIS DATA}

\section{Uji Hipotesis}

Untuk menganalisis hubungan antar variabel penelitian ini, diperlukan tiga persamaan regresi sebagai berikut:

1. Ekuitas merek = b1 komunikasi media sosial $+\mathrm{e} 1$

2. Sikap pada merek $=\mathrm{b} 2$ komunikasi media sosial $+\mathrm{e} 2$

3. Minat pembelian $=\mathrm{b} 3$ ekuitas merek $+\mathrm{b} 4$ sikap pada merek $+\mathrm{e} 3$

\section{Tabel 2}

Uji F pada ekuitas merek

\begin{tabular}{lllll}
\hline Keterangan & t & B & Sig & Keterangan \\
\hline Komunikasi & 3.660 & 0.348 & 0.000 & signifikan \\
Media Sosial & & & & \\
\hline
\end{tabular}

Tabel 3

Uji F Sikap pada merek

\begin{tabular}{lllll}
\hline Keterangan & t & B & Sig & Keterangan \\
\hline Komunikasi & 4.230 & 0.395 & 0.000 & signifikan \\
Media Sosial & & & & \\
\hline
\end{tabular}

Dari tabel di atas, diketahui bahwa p-value sebesar 0,000 lebih kecil dari 0,05 terlihat bahwa komunikasi media sosial berpengaruh masing-masing terhadap ekuitas merek dan sikap pada merek kosmetik halal.

Tabel 4

Uji F Minat pembelian kosmetik halal

\begin{tabular}{lllll}
\hline Keterangan & t & $\boldsymbol{\beta}$ & Sig & Keterangan \\
\hline Ekuitas merek & 6.614 & 0.493 & 0.000 & Signifikan \\
Sikap pada merek & 5.357 & 0.400 & 0.000 & signifikan \\
\hline
\end{tabular}

Dari tabel di atas dapat diketahui bahwa ekuitas merek dan sikap pada merek sama-sama berpengaruh terhadap minat pembelian kosmetik halal, mengarah pada terkonfirmasinya H3 (p value <0.05; t-value 6,614; $\beta$ 0,493) dan H4 ( $\mathrm{p}$ value $<0.05$; $\mathrm{t}$-value 5,$357 ; \beta 0,400$ ). 


\section{DISKUSI DAN KESIMPULAN}

Tujuan utama penelitian ini adalah untuk menghasilkan pengetahuan baru tentang bagaimana komunikasi sosial media dapat mempengaruhi ekuitas merek dan sikap pada merek dan akibatnya mempengaruhi minat membeli konsumen.

Konsumen biasanya menilai informasi yang diberikan oleh orang lain dari dapat dipercayakah dan seberapa kredibel informasi tersebut (Pornpitakpan, 2004), komunikasi media sosial memberi pengaruh terhadap persepsi merek keseluruhan. Hal ini sesuai dengan pendapat dari Yoo, Donthu, dan Lee (2000) yang menyatakan bahwa komunikasi sebuah merek berakibat positif pada ekuitas merek selama pesan yang disampaikan menciptakan reaksi konsumen yang puas akan sebuah produk dibandingkan dengan produk lain yang sejenis. Selain itu, rangsangan komunikasi menyebabkan efek positif pada konsumen, oleh karena itu persepsi komunikasi secara positif akan mempengaruhi kesadaran seseorang terhadap merek (Bruhn, Schoenmuelller, dan Schafer, 2012). Konten media sosial baik buatan perusahaan maupun dari konsumen akan mempengaruhi persepsi konsumen terhadap ekuitas merek. Hasil ini sangat bermanfaat bagi manajer merek dan komunikasi dalam membuat rencana perusahaan.

Selain itu, konten media sosial dapat menciptakan sebuah respon yang dapat membantu dalam menyebarkan promosi ke publik yang lebih besar. Dengan demikian, skenario optimal untuk manajer komunikasi adalah untuk menarik atau mendorong konsumen untuk menghasilkan konten yang mencerminkan dukungan terhadap merek dan produk perusahaan mereka. Secara khusus, perusahaan harus mensponsori komunitas online di situs media sosial yang berpengaruh dan menawarkan kepada konsumen kemampuan untuk mengembangkan hubungan dengan orang lain yang memiliki minat yang sama sehingga mereka dapat bertukar informasi dan pengalaman produk, yang secara efektif dapat menghasilkan minat membeli produk konsumen halal. Situs jejaring sosial perusahaan juga harus memungkinkan konsumen untuk tidak hanya bertukar informasi tentang produk atau layanan,tetapi juga terlibat dalam pengalaman "berpartisipasi dan bersosialisasi" (Mersley, Malthouse, dan Calder, 2010). 
Ada konsensus yang diakui bahwa komunikasi antara pelanggan merupakan sumber transmisi informasi yang berpengaruh (Dellarocas, Zhang, dan Awad 2007). Dengan adanya media sosial akan menciptakan komunikasi yang tidak terbatas antar konsumen. Perusahaan akan lebih mampu menggunakan platform media sosial untuk menargetkan populasi konsumen tertentu dengan sebuah informasi. Dalam hal ini adalah informasi tentang label halal dalam kosmetik yang mereka produksi. Dengan penjelasan ini, khususnya konsumen muslim akan lebih yakin dalam menggunakan produk tersebut.

Wilson dan Liu (2010) menyatakan bahwa sebuah merek akan menunjukkan nilainya, jika produk tersebut memiliki asosiasi produk yang kuat, unik dan menguntungkan di mata konsumen. Hal ini mendukung hipotesis yang menyatakan bahwa ekuitas merek berhubungan dengan minat pembelian kosmetik halal. Pelabelan halal ini dapat diasosiasikan sebagai citra yang positif di mata konsumen muslim sehingga akan memunculkan minat pembelian. Dengan demikian perusahaan harus mengikuti tren pelabelan halal di produk mereka untuk meningkatakan ekuitas dan penerimaan sebuah merek.

Meski penelitian ini memberi kontribusi signifikan terhadap literatur komunikasi media sosial, penelitian ini bukan tanpa batasan. Oleh karena itu, batasan penelitian kami dapat memberikan panduan untuk penelitian selanjutnya. Kami menyarankan agar semua situs media sosial terkemuka dianalisis untuk mendapatkan pemahaman yang lebih luas tentang komunikasi pemasaran melalui media sosial. Komunikasi melalui media sosial sendiri juga harus dibedakan menjadi komunikasi media sosial yang dibuat perusahaan maupun komunikasi media sosial yang dibuat oleh pengguna atau konsumen Selain itu, industri yang lebih luas harus diperiksa dalam penelitian selanjutnya. Praktik ini akan memberi indikasi bagaimana konsumen memandang merek dari berbagai industri di media sosial, tidak hanya merek berlabel halal. 


\section{DAFTAR PUSTAKA}

Aertsens, J., Mondelaers, K., Verbeke, W., Buysse, J. and Van Huylenbroeck, G. (2011), "The influence of subjective and objective knowledge on attitude, motivations and consumption of organic food", British Food Journal, Vol. 113 No. 11, pp. 13531378 .

Alam, S.S. and Sayuti, N.M. (2011b), "Applying the theory of planned behavior (TPB) in halal food purchasing", International Journal of Commerce and Management, Vol. 21 No. 1, pp. 8-20.

Al-Harran, S. and Low, P. (2008), "Marketing of halal products: the way forward", Halal Journal, available at: $\underline{w w}$.halaljournal.com

Fadahunsi, Akin \& Kargwell, Samia (2015), "Social Media, Consumer Behavior and Marketing Strategy: Implications of "Halal" on Islamic Marketing Operations", Journal of Small Business and Entrepreneurship Development .Vol. 3, No. 1, pp. $36-43$

Hunter, M. (2012), “The emerging halal cosmetic and personal care market", Personal Care, 3 March, available at:

www.researchgate.net/publication/260246427_The_Emerging_Halal_Cosmetic_a nd_Personal_Care_market (diakses pada 26 Juli 2017).

Kotler. Philip. 2003. Manajemen Pemasaran, Analisis, Perencanaan, Inplementasi dan Pengendalian (Terjemahan). Jakarta: Erlangga

Kozinets, R. V., K. De Valck, A.C. Wojnicki, and S.J.S. Wilner. (2010), Networked Narratives: Understanding Word-of-mouth Marketing in Online Communities", Journal of Marketing 74, no.March: 71-89.

Low, G., and C. Lamb Jr. (2000), "The Measurement and Dimensionality of Brand Associations", Journal of Product \& Brand Management 9, no. 6: 350-370. March: 71-89.

Mersey, Rachel Davis, Edward C. Malthouse, and Bobby J. Calder (2010), "Engagement with Online Media," Journal of Media Business Studies, 7, 2, 39-56.

Nasr, V. (2009), Forces of Fortune, Free Press, New Year, NY.

Patton, D. (2009), "Could Halal cosmetics be developing into a new global C and T niche market?", available at: www.cosmeticsbusiness.com/story.asp?storyCode $1 / 43706$ (diakses pada 26 Juli 2017).

Pornpitakpan, C. (2004) "The Persuasiveness of Source Credibility: A Critical Review of Five Decades' Evidence”, Journal of Applied Social Psychology 34, no. 2: 243281. 
Villarejo-Ramos, A.F., and M.J. Sánchez-Franco. (2005), "The Impact of Marketing Communication and Price Promotion on Brand Equity", Journal of Brand Management 12, no. 6 (August 1): 431-444.

W. Glynn Mangold a, *, David J. Faulds. (2009), "Social media: The new hybrid element of the promotion mix", Business Horizon, 52, 357-365.

Wilson, J.A.J. and Liu, J. (2010), "Shaping the Halal into a brand?", Journal of Islamic Marketing, Vol. 1 No. 2, pp. 107-123.

Wilson, Jonathan A.J \& Liu, Wilson (2010). “ Shaping the Halal into a brand?”, Journal of Islamic Marketing, Vol. 1, No. 2, 2010.

Yoo, B., and N. Donthu. (2001), "Developing and Validating a Multidimensional Consumer-based Brand Equity Scale", Journal of Business Research 52, no. 1 (April): 1-14. 